\title{
GLOSY
}

\author{
Jerzy Pielichowski
}

\section{GLOSA DO WYROKU NACZELNEGO SĄDU ADMINISTRACYJNEGO Z 8 MAJA 2015 R., II OSK 2416/13}

Interes prwny można mieć nie tylko w procesie przed sądem powszechnym, lecz także w postępowaniu przed sądem kościelnym.

1. Glosowanym orzeczeniem Naczelny Sąd Administracyjny przesądził, że zgodne z istniejącym stanem prawnym jest żądanie od Ministra Spraw Wewnętrznych przez osobę występującą w roli strony powodowej w procesie o stwierdzenie nieważności małżeństwa przed sądem kościelnym udostępnienia ze zbioru PESEL danych adresowych w postaci adresu zameldowania na pobyt stały strony pozwanej.

Przed przystąpieniem do analizy jurydycznej przypomnijmy kluczowe elementy stanu faktycznego. Powód, składając skargę powodową do sądu biskupiego, zobowiązany był podać adres strony pozwanej, aby sąd mógł ją zawiadomić o toczącym się postępowaniu (kan. 1508 $\$ 1 \mathrm{KPK}$ ) i aby strona pozwana miała możliwość skorzystania z prawa do obrony. Nie znając aktualnego adresu zameldowania na pobyt stały pozwanej, powód wnioskował do Ministra Spraw Wewnętrznych o udostępnienie go ze zbioru PESEL. Minister odmówił udostępnienia tych danych, uzasadniając, że powód nie posiada interesu prawnego w rozumieniu art. 44 h ust. 2 pkt 1 ustawy z dnia 10 kwietnia 1974 r. o ewidencji 
ludności i dowodach osobistych (w wersji obowiązującej w 2012 r.). Organ ten zaznaczył, że sąd kościelny nie jest sądem powszechnym w rozumieniu instytucji państwowej, lecz instytucją grupy wyznaniowej.

Odnośnie do osób świeckich sądy kościelne rozstrzygają w sprawach dotyczących ważności małżeństw kanonicznych. Dla omawianego tu problemu oznacza to, że osoby te posiadają interes prawny w pozyskaniu danych ze zbioru PESEL. Artykuł 10 Konkordatu między Stolicą Apostolską i Rzecząpospolitą Polską z dnia 28 lipca 1993 r. stanowi, że rozstrzyganie spraw dotyczących małżeństw kanonicznych należy do wyłącznej kompetencji władzy kościelnej.

Minister Spraw Wewnętrznych uznał, że wnioskodawca nie posiada interesu prawnego, ale wyłącznie interes faktyczny w pozyskaniu tych danych i tym samym rozpatrzył jego wniosek na podstawie art. $44 \mathrm{~h}$ ust. 2 pkt 3 ustawy o ewidencji ludności... Wynikał z niego obowiązek uwiarygodnienia interesu faktycznego i zgody osoby, których dane dotyczą. Zastosowanie tej podstawy prawnej powinno było zostać jednak poprzedzone oceną według art. $44 \mathrm{~h}$ ust. 2 pkt 1 ustawy o ewidencji ludności..., stanowiącego, że dane osobowe udostępniane są innym osobom i jednostkom organizacyjnym, jeżeli wykażą interes prawny. Konstrukcja art. 44h ust. 2 pozwalała bowiem na udostępnienie danych: „1) osobom i jednostkom organizacyjnym - jeżeli wykażą w tym interes prawny [...] 3) innym osobom i podmiotom - jeżeli uwiarygodnią one interes faktyczny w otrzymaniu danych i za zgodą osób, których dane dotyczą".

2. Na wezwanie pozwanej do wyrażenia zgody na udostępnienie danych organ nie otrzymał odpowiedzi, więc uznał, że wniosek nie spełnia przesłanki legalności udostępniania danych wynikającej z pkt 3 powyższego przepisu. Wniosek o ponowne rozpatrzenie sprawy nie przyniósł oczekiwanego efektu.

Odmowę wnioskodawca zaskarżył do Wojewódzkiego Sądu Administracyjnego, wywodząc, że posiada w udostępnieniu danych interes prawny, zatem wniosek jego powinien być uwzględniony na podstawie art. 44 h ust. 2 pkt 1 ustawy o ewidencji ludności... 
Sąd I instancji wskazał, że zgodnie z art. 44h ust. 2 ustawy o ewidencji ludności... dane osobowe są udostępniane, jak już wspomniano: po wykazaniu interesu prawnego - osobom i jednostkom organizacyjnym; jeżeli inne osoby i podmioty wykażą interes faktyczny, ale dodatkowo pod warunkiem wyrażenia zgody osoby, której dane dotyczą. W konkretnym przypadku wnioskodawca, chcąc uzyskać dane bez zgody pozwanej żony, czyli na podstawie ust. 2 pkt 1, musiał wykazać istnienie interesu prawnego.

Skarżący uzasadniał, że wnioskując o uzyskanie danych adresowych pozwanej interes prawny posiada, bo jest ona stroną w postępowaniu przed sądem kościelnym. Wojewódzki Sąd Administracyjny orzekł, że Minister Spraw Wewnętrznych wydał legalną decyzję odmowną, ponieważ interes prawny wskazany w art. $44 \mathrm{~h}$ ust. 2 pkt 1 ustawy o ewidencji ludności... powinien mieć umocowanie w konkretnej normie prawa państwowego, o czym nie może być mowy w przypadku sądownictwa wyznaniowego.

W uzasadnieniu oddalenia skargi WSA powołał się na art. 25 ust. 4 Konstytucji, stanowiący, że stosunki między Kościołem katolickim a Rzecząpospolitą Polską są określone w konkordacie i ustawach. Konkordat już w art. 1 potwierdza, że Państwo i Kościół katolicki są - każde w swej dziedzinie - niezależne i autonomiczne. Konstytucja RP stwierdza w art. 10 ust. 2, że władzę sądowniczą sprawują sądy i trybunały. Sądy kościelne zaś nie sprawują wymiaru sprawiedliwości w Rzeczypospolitej Polskiej i nie są organami świeckiej władzy sądowniczej. Te dwa piony instytucji sądowniczych różni też rozdzielność jurysdykcji - w sądach kościelnych orzeka się podług prawa kanonicznego, zaś w sądach powszechnych - obowiązującego prawa polskiego. Podsumowując, WSA stwierdził, że wniosek skarżącego nie znajdował oparcia w konkretnej powszechnie obowiązującej normie prawnej (w domyśle - należącej do polskiego porządku prawnego), która uzasadniałaby istnienie po jego stronie interesu prawnego.

W skardze kasacyjnej wnioskodawca skoncentrował się na zarzucie naruszenia art. $44 \mathrm{~h}$ ust. 2 pkt 1 ustawy o ewidencji ludności... przez bezpodstawne przyjęcie, że nie posiada interesu prawnego.

Naczelny Sąd Administracyjny uwzględnił skargę. Artykuł 44h ust. 2 pkt 1 ustawy o ewidencji ludności... stanowił, że dane z PESEL po 
wykazaniu interesu prawnego są udostępniane zainteresowanym osobom lub jednostkom organizacyjnym. Wąskie ujęcie interesu prawnego zastosowane przez Ministra Spraw Wewnętrznych zostało trafnie przez NSA poddane krytyce. Sąd wskazał, że nie wyczerpuje ono możliwości wykładni. Uprawnienie do ochrony prawnej przysługiwać może organom, które nie należą do polskiego ustroju władzy publicznej czy organów UE, ale także organom zatwierdzonych kościołów i związków wyznaniowych. Niedopuszczalne jest więc ograniczanie źródeł interesu prawnego do przepisów prawa państwowego, które regulują ustrojowe podstawy prawne funkcjonowania władzy publicznej.

3. Pogląd ten należy przyjąć z pełną akceptacją. Zgodnie z art. 87 ust. 1 Konstytucji ratyfikowane umowy międzynarodowe stanowią jedno ze źródeł powszechnie obowiązującego prawa. Tego rodzaju umową jest konkordat. Kościoły i związki wyznaniowe cieszą się autonomią, czyli same o sobie decydują i stanowią przepisy, które obowiązują członków danego wyznania również na forum publicznym - państwowym. Z tego samego powodu uznano w orzecznictwie skuteczność kanonicznych ograniczeń alienacji w porządku świeckim ${ }^{81}$.

Konkordat po ratyfikacji stał się częścią porządku prawnego w Rzeczypospolitej Polskiej i tym samym dał podstawę do uznania prawa do występowania przed sądem kościelnym za spełniające wymagania stawiane dla stwierdzenia interesu prawnego na gruncie art. 28 k.p.a. Skoro art. 10 ust. 3 konkordatu przyznał sądom kościelnym możliwość prowadzenia postępowań w sprawach o stwierdzenie nieważności małżeństwa kanonicznego, NSA przyjął, że strony powinny mieć prawo uzyskania niezbędnych informacji od organów administracji publicznej na przykład o adresie, na który mają być wysyłane pisma procesowe. Nie przekreśla tego również fakt, że w sprawach kanonicznych przyjęta jest jurysdykcja władzy kościelnej.

81 M. KAliŃski, Rozporządzanie prawami do nieruchomości należącymi do wyznaniowych osób prawnych na przykładzie Kościoła katolickiego, "Przegląd Sądowy» 4/2013, s. $28-43$. 
Niewątpliwie wyłączną kompetencją władzy kościelnej jest orzekanie o ważności małżeństwa kanonicznego, ale możliwość skutecznego występowania przed sądami kościelnymi wskutek dopuszczenia przez konkordat ich autonomicznej działalności stanowi zarazem podstawę przyjęcia interesu prawnego w świeckim prawie publicznym.

Legitymacja strony w postępowaniu administracyjnym jest skutkiem istnienia u niej interesu prawnego (art. 28 k.p.a.). Interes ten musi mieć charakter materialnoprawny oraz stwierdzać związek między sferą zindywidualizowanych praw i obowiązków wnioskodawcy wnoszącego do organu administracji a obecnym systemem prawnym.

Ostatni argument w wyprowadzeniu interesu prawnego $\mathrm{w}$ analizowanym przypadku wynika $\mathrm{z}$ wyroku Trybunału Konstytucyjnego z 2 grudnia 2009 r. ${ }^{82}$, który uznał, że unormowanie w art. 25 Konstytucji regulacji instytucjonalnej pozycji kościołów i związków wyznaniowych jako zasady ustrojowej państwa powoduje, iż interpretacja innych postanowień konstytucyjnych musi być przeprowadzana $\mathrm{w}$ „sposób przyjazny" tej zasadzie. Należy to odnieść do umożliwienia skutecznego występowania przed organami sądownictwa kościelnego. Zgoda na realizację tej kompetencji wnioskodawcy jako powoda w procesie kanonicznym byłaby naruszeniem wyrażonej w art. 25 Konstytucji zasady ustrojowej w postaci autonomii związków wyznaniowych oraz naruszeniem art. 4 pkt 1 konkordatu. Prowadziłoby zarazem do pozbawienia jednostki prawa do obrony, które realizować może wyłącznie przed organami kościelnej władzy sądowej.

Glosowany wyrok ma pośrednio doniosły skutek w zakresie usprawnienia działania sądownictwa kościelnego. Zgodnie z zasadą audiatur et altera pars, nakazującą wysłuchanie drugiej strony, prawodawstwo kościelne dąży do zachowania prawa pozwanego do wypowiedzenia się w sprawie i obrony. To uprawnienie może być spełnione, jeżeli w sposób skuteczny powiadomi się stronę pozwaną o toczącym się postępowaniu. Sprawy dotyczące stwierdzenia nieważności małżeństwa kanonicznego obarczone są nieraz negatywnym ładunkiem emocjonalnym między (przeważnie już rozwiedzionymi) małżonkami. Z chwilą zerwania więzi

82 U 10/07, «OTK-A» 11/2009, poz. 163. 
małżeńskich tracą oni ze sobą kontakt i często nie posiadają wiedzy o aktualnych danych adresowych byłego współmałżonka.

4. Ustawa z 24 września 2010 r. o ewidencji ludności weszła w życie 1 marca 2015 r. i uchyliła w całości art. 44 poprzedniej ustawy z 10 kwietnia 1974 r. o ewidencji ludności i dowodach osobistych, przenosząc do art. 46 ust. 2 pkt 1 treść przepisu o udzieleniu danych z baz PESEL podmiotom, które wykażą interes prawny.

Ustawa z 23 lipca 2015 r. o zmianie ustawy o ewidencji ludności przesuwała termin zniesienia obowiązku meldunkowego na dzień 1 stycznia 2018 r. Z tą datą zbiory PESEL miały utracić walor źródła wiedzy o miejscu stałego zameldowania i tym samym przekreślić możliwość występowania do ministra o udostępnienie tych danych. Jednak 27 października 2017 r. Sejm uchwalił nowelizację tej ustawy, która wchodząc w życie od 1 stycznia 2018 r., utrzymała obowiązek meldunkowy, a w przypadku braku numeru PESEL - dała możliwość uzyskania go z urzędu przy składaniu wniosku o wydanie dowodu osobistego. Ustawodawca, uzasadniając pozostawienie obowiązku meldunkowego, wskazał na usprawnienie działań administracji oraz przeciwdziałanie zagrożeniom terrorystycznym. Obowiązek ten łączy się z gromadzeniem w zbiorze PESEL danych o miejscu zamieszkania.

Ocena zachowania obowiązku meldunkowego w znacznej mierze wykracza poza obszar niniejszego opracowania. Odnośnie jednak do problemu przedstawionego w glosowanym wyroku zachowanie tego obowiązku, i co za tym idzie, możliwość tworzenia wiarygodnych baz adresowych osób zameldowanych na terenie RP, trzeba ocenić pozytywnie. Dzięki istnieniu tych baz powód kanoniczny może - wykazując interes prawny - uzyskać dostęp do danych adresowych strony postępowania o stwierdzenie nieważności małżeństwa kanonicznego. 